\title{
Impact of Rheumatoid Arthritis Functional Status on Oral and Periodontal Health in a Multi-Ethnic Population
}

(Kesan Kefungsian Status Artritis Reumatoid ke atas Kesihatan Mulut dan Periodon Penduduk Berbilang Kaum)

\author{
NIK-MADIHAH NiK-AZIS*, FAZALINA MOHD FADZILAH, MOHD SHAHRIR MOHAMED SAID, \\ BADIAH BAHARIN \& NURULHUDA MOHD
}

\begin{abstract}
Periodontal disease (PD) has both been associated with the pathogenesis of Rheumatoid Arthritis (RA) and is also a comorbidity of $R A$. The aim of this study was to investigate the impact of the functional status of RA on oral and periodontal health in a multi-ethnic population. This is a hospital-based, multi-ethnic, observational study. Duration of illness, Disease Activity Score (DAS28), seropositivity and other rheumatological parameters were obtained from the records of RA patients attending the Rheumatology Clinic. Oral health examination was conducted on the subjects. Their functional status was assessed using the Health Assessment Questionnaire (HAQ) which includes categories in 'dressing', 'rising', 'eating', 'walking', 'hygiene', 'reach', 'grip' and 'usual activities'. Data were analysed using ANOVA or Kruskal-Wallis test and Pearson's Correlation or Spearman's Rank Correlation Test. The 63 RA patients recruited had a mean disease duration of $10.7 \pm 9.85$ years with a mean of 19.9 teeth $( \pm 7.18)$. The severity of PD worsens the longer the patients were suffering from RA ( $\mathrm{p}=0.028)$. A high frequency (70\%) of PD with $27 \%$ moderate and $27 \%$ severe, was observed. A significant association ( $\mathrm{p}=0.035)$ was found between the 'eating' category of the HAQ and the average periodontal pocket depth. This study shows that there is a higher prevalence and severity of PD among RA patients in the selected population. The impact of functional status on periodontal health is mostly in the 'eating'category of the HAQ where patients reporting a disability in eating had higher average periodontal pocket depth.
\end{abstract}

Keywords: Function; health assessment questionnaire; periodontal disease; Rheumatoid Arthritis

\section{ABSTRAK}

Kajian terkini mengaitkan penyakit periodon (PD) sama ada sebagai punca penyakit Rheumatoid Arthritis (RA) atau sebagai kesan daripada penyakit RA. Kajian ini bertujuan untuk melihat kesan keupayaan dan fungsi dalam kalangan pesakit RA ke atas PD dalam populasi yang terdiri daripada pelbagai etnik. Kajian ini merupakan kajian keratan rentas berpusat di hospital. Jangka masa penyakit, Disease Activity Score (DAS28), status seropositif dan lain-lain maklumat perubatan diperoleh daripada rekod pesakit RA yang hadir ke klinik reumatologi. Pemeriksaan mulut turut dijalankan. Keupayaan fungsi pesakit dinilai menggunakan Soal Selidik Penilaian Kesihatan (HAQ) yang mempunyai kategori 'memakai pakaian', 'bangun', 'makan', 'berjalan', 'kebersihan', 'jangkauan', 'genggaman'dan 'aktiviti harian'. Data dianalisis menggunakan ujian ANOVA atau Kruskal-Wallis serta Korelasi Pearson atau Korelasi Tingkat Spearman. 63 pesakit RA yang dikaji mempunyai purata penyakit 10.7 \pm 9.85 tahun dan purata gigi 19.9 batang ( \pm 7.18 ). Semakin lama pesakit menderita dengan penyakit RA, penyakit PD didapati menjadi lebih serius $(\mathrm{p}=0.028)$. Pesakit RA juga mempunyai PD dengan frekuensi yang tinggi (70\%) dengan 27\% adalah sederhana dan $27 \%$ pula serius. Terdapat kaitan yang signifikan ( $\mathrm{p}=0.035)$ antara kategori 'makan'di dalam HAQ dan purata kedalaman poket periodon. Kajian ini menunjukkan bahawa frekuensi penyakit PD dalam kalangan pesakit RA adalah lebih tinggi dan lebih serius. Pesakit yang mempunyai keupayaan dan fungsi 'makan' yang terjejas juga didapati mempunyai kedalaman poket periodon lebih tinggi.

Kata kunci: Fungsi dan keupayaan; soal selidik penilaian kesihatan; penyakit periodontal; Rheumatoid Arthritis

\section{INTRODUCTION}

Periodontal disease (PD) is probably the most common disease in mankind; characterised by infection and inflammation of the structures supporting the teeth (Tonetti et al. 2017). It is typically characterised by inflammation of the gums, tooth mobility, gum recession and halitosis. Rheumatoid arthritis (RA) is a chronic autoimmune inflammatory disease classically presenting with chronic, bilateral and symmetrical polyarthritis and joint tenderness.
The disease progression is mostly influenced by the autoimmunity and the overall systemic and articular inflammatory load (Aletaha et al. 2010).

The link between RA and PD has been widely investigated. Its interrelationship can be explained by the role of the periodontal pathogenic bacteria Porphyromonas gingivalis (Scher et al. 2012) or other bacteria that are able to express the enzyme peptidylarginine deiminase (PAD) which has the capacity to generate citrullinated 
proteins and peptides, hence triggering autoantibodies in RA pathogenesis (Konig et al. 2016; McHugh 2017). There are also reports on PD as a comorbidity of RA either due to poor oral hygiene or increased serum inflammatory mediators impacting on the gingivae or vice versa (Abrão et al. 2016; Araujo et al. 2015; Kaur et al. 2013).

RA patients have varying functional status depending on the disease activity, severity, duration of the disease and the distribution of the joints affected by the disease. The effects of RA on hand function is thought to impair the patients' ability to perform oral hygiene measures, hence causing an increase in the PD parameters in this population (Feldman et al. 1983; Garib \& Qaradaxi 2011; Pischon et al. 2008). Those with RA may also have function (Young et al. 2000) and nutrition issues (Mizukami et al. 2017) secondary to their disease and this too may have an influence on their periodontal health.

Studies reporting on the impaired function of RA patients generally used the Health Assessment Questionnaire (HAQ) to assess the function and level of disability (Mercado et al. 2001). Mercado et al. (2001) found a relationship between the degree of functional debilitation due to RA and PD severity while Garib and Qaradaxi (2011) also reported a relationship between HAQ scores with plaque index, alveolar bone loss and clinical attachment loss of the periodontium. In contrast, Schmickler et al. (2016) used self-reported limitations in motor skills reported in a self-administered questionnaire to assess function and found that limited motor skills had no influence on periodontal conditions (Schmickler et al. 2016). This is in line with the HAQ scores from other reports (Bello-Gualtero et al. 2015; Dissick et al. 2010) that were not associated with measures of oral or periodontal disease.

It is worth noting that the HAQ is a global assessment of function and disability without differentiating between those involving the hands specifically. The aforementioned studies did not differentiate on the type of disability, whether it involves only the upper extremities or also the lower extremities. Only one report was found that analysed the scores for the categories involving the hand separately utilizing the Thai HAQ (Khantisopon et al. 2014). This study showed that the mean upper extremity HAQ hand score was $0.66 \pm 0.68$, and $9.7 \%$ had upper extremity $\mathrm{HAQ} \geq 2$ in the Thai RA population. However, the authors did not report on the association between the HAQ score with the periodontal parameters.

The nature of the relationship between functional status in RA patients with PD remains poorly investigated. To date, there is a paucity of studies in this regard to derive firm conclusions. Hence, we aim to investigate the effect of functional status in RA patients on PD parameters.

\section{METHODS}

\section{STUDY POPULATION}

Ethical approval for the study was obtained from Ethical Board of Universiti Kebangsaan Malaysia and the study was conducted in accordance with the Helsinki Declaration of 1975. Subjects were recruited from the Rheumatology Clinic of Universiti Kebangsaan Malaysia Medical Centre and those who consented and fulfilled the inclusion and exclusion criteria were enrolled in this study.

This is an observational study where the inclusion criteria for the RA patients were: Patients who fulfilled The American College of Rheumatology 2010 criteria for RA; patients aged 18 years and above; patients who were able to provide written or verbal consent; and patients who were dentate. The exclusion criteria were: Patients who were completely unable to read, write, or understand Malay or English Language; coexistence of other autoimmune diseases; uncontrolled systemic disease or malignancy; patients who were pregnant or planning to become pregnant; and current or previous history of periodontal treatment.

\section{ORAL EXAMINATION}

Oral examinations of the subjects with RA were performed by a single examiner using a manual periodontal probe (PCP-UNC 15; Hu-Friedy, Chicago, IL, USA). The periodontal parameters were obtained at six sites for each tooth namely the mesio-buccal, mid-buccal, disto-buccal, mesiolingual, midlingual and disto-lingual surfaces.

The plaque index (PI) was evaluated according to Leary et al. (1972) and the gingival index (GI) was assessed according to Ainamo and Bay (1975). In addition, the Decayed, Missing Filled Teeth (DMFT) index, according to Klein and Palmer ${ }^{(1983)}$ was recorded. The periodontal disease was classified according to the Centre for Disease Control and Prevention in partnership with the American Academy of Periodontology definitions (Eke et al. 2012).

\section{HEALTH ASSESSMENT QUESTIONNAIRE - DISABILITY (HAQ-DI)}

The HAQ-DI is the most widely used tool for functional assessment in RA (Bruce \& Fries 2003). It assesses a patient's level of functional ability involving fine movements of the upper extremity and locomotor activities of the lower extremity. There are 20 questions in eight categories that represent a comprehensive set of common daily activities: dressing, rising, eating, walking and hygiene. Higher scores indicate more disability $(0 \geq$ without any difficulty; $1 \geq$ with some difficulty; $2 \geq$ with much difficulty; and $3 \geq$ unable to do).

\section{STUDY PROTOCOL}

The demographic data such as age, sex, race, smoking status and body mass index (BMI) of all participants were recorded. Rheumatological indicators such as their seropositivity (rheumatoid factor and anti-citrullinated protein antibody), Disease Activity Score in 28 joints (DAS 28 ), medications and laboratory parameters were extracted from the medical records of the RA patients. 
These patients were assessed for their Health Assessment Questionnaire Disability Index (HAQ-DI) scores by means of an interview conducted by a single interviewer.

A full oral health check-up including a periodontal chart, plaque score and bleeding on probing scores was conducted by a single examiner. The patients' DecayedMissing-Filled Teeth (DMFT) were also calculated.

\section{STATISTICAL ANALYSIS}

All data were analysed using SPSS version 21.0 (SPSS Inc., Chicago, IL, USA). The continuous variables were tested for normality using the Kolmogorov Smirnov or Shapiro-Wilk test. Data with a normal distribution were analyzed using ANOVA and expressed as mean \pm standard deviation. The data that were skewed or with no particular distribution, by contrast, were analysed using the Kruskal-Wallis test. The relationship between two continuous variables was determined using Pearson's Correlation for normally distributed data and Spearman's Rank Correlation Test for the non-parametric data. A $P$ value of $<0.05$ was considered statistically significant.

\section{RESULTS}

\section{SOCIODEMOGRAPHIC DATA}

A total of 63 patients were enrolled in this study. Their sociodemographic characteristics are summarised in Table 1. The mean age of the subjects was $56 \pm 11.8$ years with the subjects being predominantly female $(92 \%)$. The distribution of the ethnic groups is shown in Table 1 with Malay, Chinese and Indian descent representing $98 \%$ of the subjects. A high proportion of the subjects (70\%) suffered from PD with $27 \%$ of these being severe.

\section{FUNCTIONAL STATUS AND ORAL HEALTH PARAMETERS}

Figure 1 categorises the oral health parameters namely the Gingival Index, Plaque Index, DMFT, average tooth count and average Probing Pocket depth according to the RA functional status. Overall, there was no statistical difference in the oral health parameters when sorted according to the functional status of the subjects.
TABLE 1. Sociodemographic background of subjects

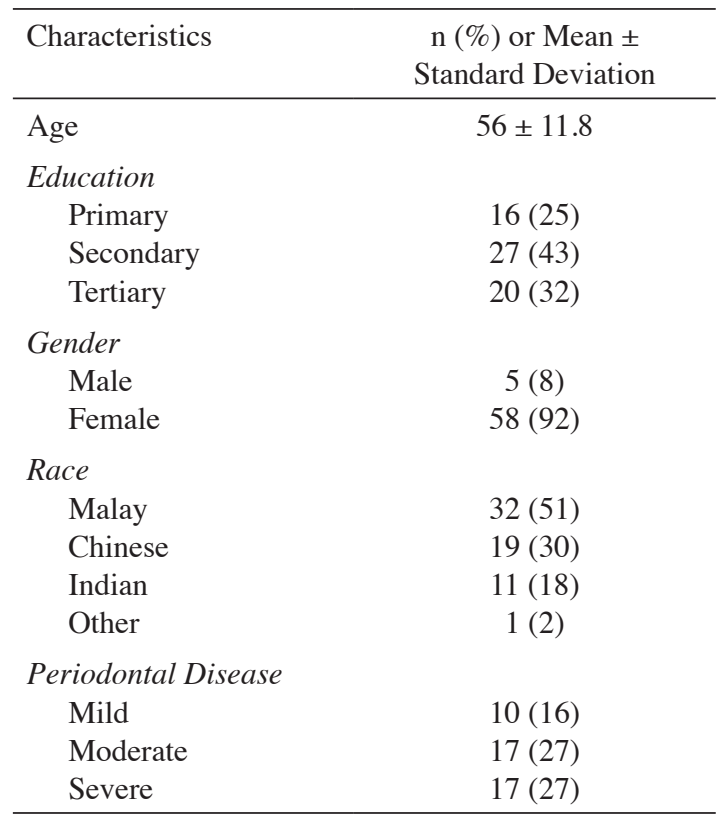

\section{COMORBIDITIES AND RA PARAMETERS ACCORDING} TO PD SEVERITY

The distribution of the subjects according to the severity of their PD is shown in Table 2. Only 5\% $(n=3)$ of the subject were smokers and 3\% $(n=2)$ were past smokers. Comorbidities namely the BMI and smoking status of the subjects had no impact on the severity of their PD. Differences between the levels of the markers of RA disease activity such as ESR, CRP and DAS28 were also not statistically significant between the different groups.

The mean duration of RA in the subjects was $10.7 \pm$ 9.85 years. Among the different parameters of RA, only disease duration showed statistical significance $(P=0.028)$ where subjects who suffered from RA for a longer duration had a more severe form of PD.

\section{ORAL HEALTH PARAMETERS AND HAQ-DI CATEGORIES}

Table 3 shows the correlation between the different oral health parameters and the HAQ-DI categories. Only the category 'eating' showed a statistically significant

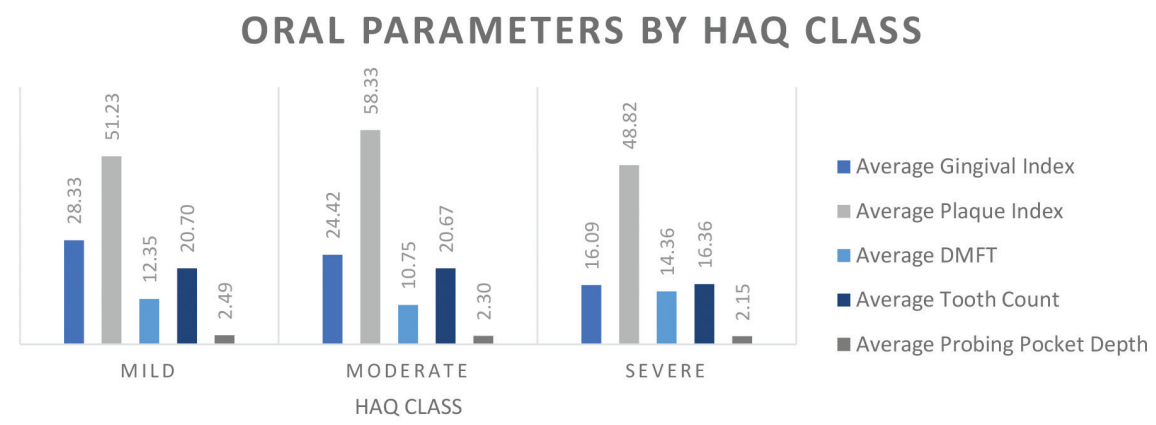

FIGURE 1. Characteristics of oral and periodontal health parameters in relation to RA functional status 
TABLE 2. Comparison of comorbidities and RA-related variables between subjects with different PD severity

\begin{tabular}{|c|c|c|c|c|c|c|}
\hline & All (N=63) & $\begin{array}{l}\text { No Periodontitis } \\
\quad(n=19)\end{array}$ & $\begin{array}{c}\text { Mild } \\
\text { Periodontitis } \\
(n=10)\end{array}$ & $\begin{array}{c}\text { Moderate } \\
\text { Periodontitis } \\
\quad(n=17)\end{array}$ & $\begin{array}{c}\text { Severe } \\
\text { Periodontitis } \\
\quad(n=17)\end{array}$ & $P$-value \\
\hline Disease Duration & & & & & & $P=0.028^{*}$ \\
\hline Short $(<1$ year $)$ & $8(12.9)$ & $2(3.2)$ & $0(0)$ & $6(9.7)$ & $0(0)$ & \\
\hline Medium (1-6 years) & $21(33.9)$ & $8(12.9)$ & $3(4.8)$ & $2(3.2)$ & $8(12.9)$ & \\
\hline Long (> 6 years $)$ & $33(53.2)$ & $9(14.5)$ & $6(9.7)$ & $9(14.5)$ & $9(14.5)$ & \\
\hline Mean \pm SD & $10.7 \pm 9.85$ & $10.0 \pm 9.20$ & $16.8 \pm 14.54$ & $8.7 \pm 8.52$ & $9.8 \pm 7.73$ & $P=0.232$ \\
\hline Disease Activity (DAS28) & & & & & & $P=0.460$ \\
\hline Remission $(\leq 2.6)$ & $11(17.5)$ & $1(1.6)$ & $4(6.3)$ & $3(4.8)$ & $3(4.8)$ & \\
\hline Low $(2.6<D A S 28 \leq 3.2)$ & $28(44.4)$ & $10(15.9)$ & $3(4.8)$ & $7(11.1)$ & $8(12.7)$ & \\
\hline Moderate $(3.2<$ DAS $28 \leq 5.1)$ & $24(38.1)$ & $8(12.7)$ & $3(4.8)$ & $7(11.1)$ & $6(9.5)$ & \\
\hline Mean \pm SD & $1.21(0.722)$ & $1.37(0.597)$ & $0.90(0.876)$ & $1.24(0.752)$ & $1.18(0.728)$ & $P=0.560$ \\
\hline Rheumatoid Factor & & & & & & $P=0.218$ \\
\hline Positive ( $\geq 20 \mathrm{U} / \mathrm{mL}$ ) & $38(60.3)$ & $14(22.2)$ & $3(4.8)$ & $10(15.9)$ & $11(17.5)$ & \\
\hline Negative $(<20 \mathrm{U} / \mathrm{mL})$ & $20(31.7)$ & $3(4.8)$ & $5(7.9)$ & $6(9.5)$ & $6(9.5)$ & \\
\hline Not Available & $5(7.9)$ & $2(3.2)$ & $2(3.2)$ & $1(1.6)$ & $0(0)$ & \\
\hline Anti-CCP & & & & & & $P=0.259$ \\
\hline Positive ( $\geq 5 \mathrm{U} / \mathrm{mL}$ ) & $19(30.2)$ & $8(12.7)$ & $3(4.8)$ & $1(1.6)$ & $7(11.1)$ & \\
\hline Negative $(<5 \mathrm{U} / \mathrm{mL})$ & $9(14.3)$ & $2(3.2)$ & $1(1.6)$ & $3(4.8)$ & $3(4.8)$ & \\
\hline Not Available & $35(55.6)$ & $9(14.3)$ & $6(9.5)$ & $13(20.6)$ & $7(11.1)$ & \\
\hline ESR & & & & & & $P=0.228$ \\
\hline $\operatorname{Normal}(1-20 \mathrm{~mm} / \mathrm{Hr})$ & $4(6.3)$ & $1(1.6)$ & $2(3.2)$ & $0(0)$ & $1(1.6)$ & \\
\hline $\operatorname{High}(>20 \mathrm{~mm} / \mathrm{Hr})$ & 59 (93.7) & $18(28.6)$ & $8(12.7)$ & $17(27.0)$ & $16(25.4)$ & \\
\hline Mean \pm SD & $52.1 \pm 23.74$ & $60.0 \pm 23.50$ & $46.2 \pm 33.27$ & $46.8 \pm 17.11$ & $52.0 \pm 22.88$ & $P=0.357$ \\
\hline CRP & & & & & & $P=0.10$ \\
\hline $\operatorname{Normal}(\leq 0.5 \mathrm{mg} / \mathrm{dL})$ & $28(44.4)$ & $4(6.3)$ & $5(7.9)$ & $10(15.9)$ & $9(14.3)$ & \\
\hline $\operatorname{High}(>0.5 \mathrm{mg} / \mathrm{dL})$ & $35(55.6)$ & $15(23.8)$ & $5(7.9)$ & $7(11.1)$ & $8(12.7)$ & \\
\hline Mean \pm SD & $1.2 \pm 1.62$ & $1.6 \pm 1.81$ & $1.3 \pm 1.54$ & $0.6 \pm 0.53$ & $1.3 \pm 2.07$ & $P=0.084$ \\
\hline HAQ Score & & & & & & $P=0.326$ \\
\hline Mild Disability (0-1) & $40(63.5)$ & $10(15.9)$ & $6(9.5)$ & $14(22.2)$ & $10(15.9)$ & \\
\hline Moderate Disability (1-2) & $12(19)$ & $5(7.9)$ & $2(3.2)$ & $3(4.8)$ & $2(3.2)$ & \\
\hline Severe Disability (2-3) & $11(17.5)$ & $4(6.3)$ & $2(3.2)$ & $0(0)$ & $5(7.9)$ & \\
\hline Mean \pm SD & $0.69 \pm 0.900$ & $0.82 \pm 0.908$ & $0.76 \pm 1.097$ & $0.368 \pm 0.563$ & $0.82 \pm 1.035$ & $P=0.885$ \\
\hline
\end{tabular}

Chi-squared test of contingencies to test whether the categorical data is related, ANOVA or Mann-Whitney to test the differences between the groups. $\mathrm{SD}=\mathrm{Standard}$ Deviation; BMI= Body Mass Index; Anti-CCP= Anti Cyclic Citrullinated Protein Antibodies; ESR= Erythrocyte Sedimentation Rate; $\mathrm{CRP}=\mathrm{C}$-reactive Protein; HAQ= Health Assessment Questionnaire

correlation with the average probing pocket depth at $P=$ 0.035 . None of the other oral health parameters showed any correlation with the different HAQ categories.

\section{DISCUSSION}

This is a novel report on the prevalence of PD among RA patients in a multi-ethnic population of Asian descent in Malaysia. There are only two other studies on this relationship in the South-East Asia region, both with conflicting findings where one reported a higher prevalence of PD among RA patients (Khantisopon et al. 2014) while the other (Susanto et al. 2013) did not show any association.
In this study, there was a higher prevalence and severity of PD among RA patients compared to the Malaysia population when we modified our data according to the Community Periodontal Index similar to the Malaysian National Oral Health Survey in Adults (2010). Our findings are comparable to reports from Thailand (Khantisopon et al. 2014), Korea (Choi et al. 2016), Taiwan (Chen et al. 2013) and India (Joseph et al. 2013) among others. In contrast, studies from Indonesia (Susanto et al. 2013) and Sweden (Eriksson et al. 2016) did not find an increased prevalence of PD among RA patients.

The dissimilarity in the prevalence reports may be due to the differences in the population studied. Genes 


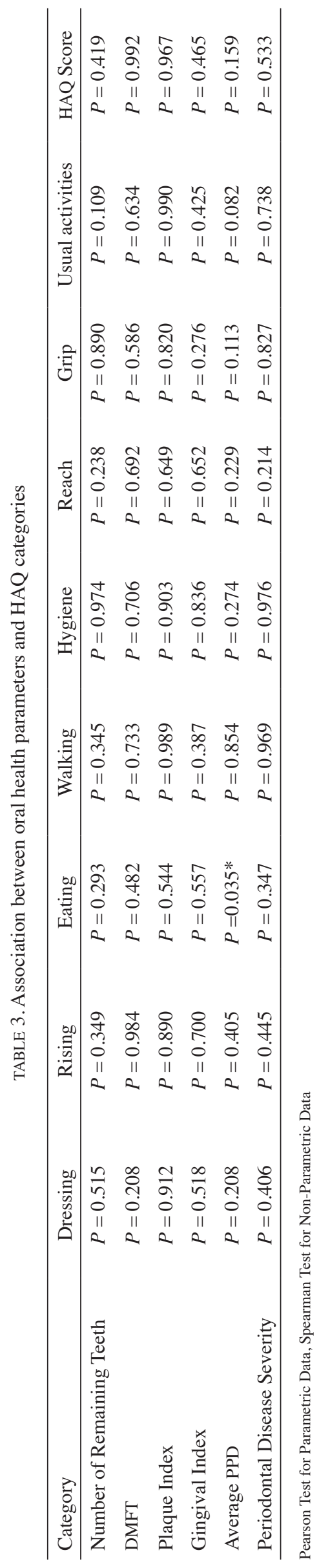


specifically those within the human leukocyte antigen (HLA) region, particularly the HLA-DRB1 genes have been shown to influence both the susceptibility to RA (Bowes \& Barton 2008) and PD (Takashiba et al. 1999). Despite the differences in the genetic make-up of the HLA-DR genes amongst Malay, Chinese and Indian ethnic groups in Malaysia (Kong et al. 2002), this study found no differences in the prevalence and severity of PD between the different aforesaid ethnicity.

It was hypothesised that with an increasing RA duration, there will be a decrease in manual dexterity, leading to an impaired ability to perform oral hygiene care. Accumulation of plaque will consequently lead to an increase in clinical attachment loss, bone loss and eventually tooth loss. To validate this premise, an association between HAQ scores and periodontal disease parameters specifically markers for oral hygiene is needed. However, no association between the overall HAQ scores with oral hygiene was found in this study. This is similar to other studies reporting on this connection (Bello-Gualtero et al. 2015; Dissick et al. 2010; Schmickler et al. 2016).

Seropositive RA patients has a greater tendency to deformity (Edelman \& Russell 1983). This deformity may account for the higher PD prevalence and severity associated with seropositive RA specifically the positive anti-citrullinated protein antibodies (Choi et al. 2016; Gonzalez et al. 2014; Mikuls et al. 2014; Potikuri et al. 2012). However, there was no difference in the PD severity based on either the rheumatoid factor or the anti-cyclic citrullinated protein antibodies in this study. Nevertheless, this may be limited by the incomplete data on seropositivity markers in more than half of our subjects.

This study showed an association between the 'eating' category of the HAQ with average probing pocket depth $(p=0.035)$. This suggests that RA patients with nutrition issues may be more predisposed to PD. Since diet and nutrition have been suggested as factors that plays a role in both RA (McCann 2017; Yuki 2007) and PD (Raindi 2016; Shariq et al. 2016), it is likely that this is one of the factors contributing to the increased prevalence and severity of PD in this group of patients.

This study has some drawbacks. The assessment of function and disability was limited to those assessed by the HAQ. Ideally, other means of assessment including hand function tests, grip strength test, and Arthritis Impact Measurement Scale (Meenan 1992) can be employed to get a better representation of hand function. A more objective measurement of hand function will give a better picture on the ability of RA patients to perform regular oral hygiene care.

\section{CONCLUSION}

This study has shown that there is a higher prevalence and severity of PD among RA patients in the selected Malaysian Population. The duration of the RA effects the severity of PD. The impact of functional status on periodontal health is mostly in the 'eating' category of the HAQ where patients reporting a disability in eating had a higher average periodontal pocket depth.

\section{REFERENCES}

Abrão, A.L.P., Santana, C.M., Bezerra, A.C.B., de Amorim, R.F.B., da Silva, M.B., da Mota, L.M.H. \& Falcão, D.P. 2016. What rheumatologists should know about orofacial manifestations of autoimmune rheumatic diseases. Revista Brasileira de Reumatologia 56(5): 441-450.

Ainamo, J. \& Bay, I. 1975. Problems and proposals for recording gingivitis and plaque. International Dental Journal 25(4): 229-235.

Aletaha, D., Neogi, T., Silman, A.J., Funovits, J., Felson, D.T., Bingham, C.O., Birnbaum, N.S., Burmester, G.R., Bykerk, V.P., Cohen, M.D., Combe, B., Costenbader, K.H., Dougados, M., Emery, P., Ferraccioli, G., Hazes, J.M.W., Hobbs, K., Huizinga, T.W.J., Kavanaugh, A., Kay, J., Kvien, T.K., Laing, T., Mease, P., Ménard, H.A., Moreland, L.W., Naden, R.L., Pincus, T., Smolen, J.S., Stanislawska-Biernat, E., Symmons, D., Tak, P.P., Upchurch, K.S., Vencovský, J., Wolfe, F. \& Hawker, G. 2010. 2010 rheumatoid arthritis classification criteria: An American College of Rheumatology/European League against rheumatism collaborative initiative. Arthritis \& Rheumatology 62(9): 2569-2581.

Araujo, V.M.A., Melo, I.M. \& Lima, V. 2015. Relationship between periodontitis and rheumatoid arthritis: Review of the literature. Mediators of Inflammation 2015: 259074.

Bello-Gualtero, J.M., Lafaurie, G.I., Hoyos, L.X., Castillo, D.M., De-Avila, J., Munevar, J.C., Unriza, S., Londoño, J., ValleOñate, R. \& Romero-Sanchez, C. 2015. Periodontal disease in individuals with a genetic risk of developing arthritis or with early rheumatoid arthritis: A cross-sectional study. Journal of Periodontal 87(4): 346-356.

Bowes, J. \& Barton, A. 2008. Recent advances in the genetics of RA susceptibility. Rheumatology (Oxford) 47(4): 399-402.

Bruce, B. \& Fries, J.F. 2003. The Stanford health assessment questionnaire: Dimensions and practical applications. Health and Quality of Life Outcomes 1: 20.

Chen, H.H., Huang, N., Chen, Y.M., Chen, T.J., Chou, P., Lee, Y.L., Chou, Y.J., Lan, J.L., Lai, K.L., Lin, C.H. \& Chen, D.Y. 2013. Association between a history of periodontitis and the risk of rheumatoid arthritis: A nationwide, population-based, case-control study. Annals of Rheumatic Diseases 72(7): 1206-1211.

Choi, I.A., Kim, J., Kim, Y.M., Lee, J.Y., Kim, K.H., Lee, E.Y., Lee, E.B., Lee, Y. \& Song, Y.W. 2016. Periodontitis is associated with rheumatoid arthritis: A study with longstanding rheumatoid arthritis patients in Korea. The Korean Journal of Internal Medicine 31(5): 977-986.

Dissick, A., Redman, R.S., Jones, M., Rangan, B.V., Reimold, A., Griffiths, G.R., Mikuls, T.R., Amdur, R.L., Richards, J.S. \& Kerr, G.S. 2010. Association of periodontitis with rheumatoid arthritis: A pilot study. Journal of Periodontology 81(2): 223-230.

Edelman, J. \& Russell, A.S. 1983. A comparison of patients with seropositive and seronegative rheumatoid arthritis. Rheumatology International 3: 47-48.

Eke, P.I., Page, R.C., Wei, L., Thornton-Evans, G. \& Genco, R.J. 2012. Update of the case definitions for population-based surveillance of periodontitis. Journal of Periodontology 83(12): 1449-1454 
Eriksson, K., Nise, L., Kats, A., Luttropp, E. \& Catrina, A.I. 2016. Prevalence of periodontitis in patients with established rheumatoid arthritis: A Swedish population based casecontrol study. PloS ONE 11(5): e0155956.

Feldman, R.O.Y.S., Szeto, B. \& Uncev, H.H.C. 1983. Nonsteroidal anti-inflammatory drugs in the reduction of human alveolar bone loss. Journal of Clinical Periodontology 10: 131-136.

Garib, B.T. \& Qaradaxi, S.S. 2011. Temporomandibular joint problems and periodontal condition in rheumatoid arthritis patients in relation to their rheumatologic status. Journal of Oral and Maxillofacial Surgery 69(12): 2971-2978.

Gonzalez, S.M., Payne, J.B., Yu, F., Thiele, G.M., Erickson, A.R., Johnson, P.G., Schmid, M.J., Cannon, G.W., Kerr, G.S., Reimold, A.M., Sokolove, J., Robinson, W.H. \& Mikuls, T.R. 2014. Alveolar bone loss is associated with circulating anti-citrullinated protein antibody (ACPA) in patients with rheumatoid arthritis. Journal of Periodontology 86(2): 222231.

Joseph, R., Rajappan, S., Nath, S.G. \& Paul, B.J. 2013. Association between chronic periodontitis and rheumatoid arthritis: A hospital-based case-control study. Rheumatology International 33(1): 103-109.

Kaur, S., White, S. \& Bartold, P.M. 2013. Periodontal disease and rheumatoid arthritis: A systematic review. Journal of Dental Research 92(5): 399-408.

Khantisopon, N., Louthrenoo, W., Kasitanon, N., Sivasomboon, C., Wangkaew, S., Sang-In, S., Jotikasthira, N. \& Bandhaya, P. 2014. Periodontal disease in Thai patients with rheumatoid arthritis. International Journal of Rheumatic Diseases 17(5): 511-518.

Klein, H. \& Palmer, C. 1938. Studies on dental caries. Public Health Reports 53(38): 1685-1732.

Kong, K., Yeap, S., Chow, S. \& Phipps, M.E. 2002. HLA-DRB1 genes and susceptibility to rheumatoid arthritis in three ethnic groups from Malaysia. Autoimmunity 35(4): 235-239.

Konig, M.F., Abusleme, L., Reinholdt, J., Palmer, R.J., Teles, R.P., Sampson, K., Rosen, A., Nigrovic, P.A., Sokolove, J., Giles, J.T., Moutsopoulos, N.M. \& Andrade, F. 2016. Aggregatibacter actinomycetemcomitans-induced hypercitrullination links periodontal infection to autoimmunity in rheumatoid arthritis. Science Translational Medicine 8(369): 1-13.

Leary, J.O., Drake, B. \& Naylor, J.E. 1972. The plaque control record. Journal of Periodontology 43(1): 38.

McCann, K. 2007. Nutrition and rheumatoid arthritis. Explore (NY) 3(6): 616-618.

McHugh, J. 2017. Rheumatoid arthritis: New model linking periodontitis and RA. Nature Reviews Rheumatology 13(2): 66.

Meenan, R.F., Mason, J.H., Anderson, J.J., Guccione, A.A. \& Kazis, L.E. 1992. AIMS2. The content and properties of a revised and expanded arthritis impact measurement scales health status questionnaire. Arthritis \& Rheumatology 35(1): 1-10.

Mercado, F.B., Marshall, R.I., Klestov, A.C. \& Bartold, P.M. 2001. Arthritis and periodontitis. Journal of Periodontology 72: 779-787.

Mikuls, T.R., Payne, J.B., Yu, F., Thiele, G.M., Reynolds, R.J., Cannon, G.W., Markt, J., McGowan, D., Kerr, G.S. \& Redman, R.S. 2014. Periodontitis and Porphyromonas gingivalis in patients with rheumatoid arthritis. Arthritis \& Rheumatology 66(5): 1090-1100.
Mizukami, Y., Matsui, T., Tobma, S. \& Masuko, K. 2017. Distinct patterns of dietary intake in different functional classes of patients with rheumatoid arthritis. Topics in Clinical Nutrition 32(2): 141-151.

Pischon, N., Pischon, T., Kroger, J., Gulmez, E., Kleber, B.M., Bernimoulin, J.P., Landau, H., Brinkmann, P.G., Schlattmann, P., Zernicke, J., Buttgereit, F. \& Detert, J. 2008. Association among rheumatoid arthritis, oral hygiene, and periodontitis. Journal of Periodontology 79(6): 979-986.

Potikuri, D., Dannana, K.C., Kanchinadam, S., Agrawal, S., Kancharla, A., Rajasekhar, L., Pothuraju, S. \& Gumdal, N. 2012. Periodontal disease is significantly higher in non-smoking treatment-naive rheumatoid arthritis patients: Results from a case-control study. Annals of Rheumatic Diseases 71: 1541-1544.

Raindi, D. 2016. Nutrition and periodontal disease. Dental Update 43(1): 66-68, 71-72.

Scher, J.U., Ubeda, C., Equinda, M., Khanin, R., Buischi, Y., Viale, A., Lipuma, L., Attur, M., Pillinger, M.H., Weissmann, G., Littman, D.R., Pamer, E.G., Bretz, W.A. \& Abramson, S.B. 2012. Periodontal disease and the oral microbiota in new-onset rheumatoid arthritis. Arthritis \& Rheumatology 64(10): 3083-3094.

Schmickler, J., Rupprecht, A., Patschan, S., Patschan, D. \& Gerhard, A. 2016. Cross-sectional evaluation of periodontal status, microbiological and rheumatoid parameters in a large cohort of patients with rheumatoid arthritis. Journal of Periodontal 88(4): 368-379.

Shariq, N., Zafar, M.S., Khurshid, Z., Sana, Z. \& Almas, K. 2016. The role of nutrition in periodontal health: An update. Nutrients 8(9): 530.

Susanto, H., Nesse, W., Kertia, N., Soeroso, J., Huijser van Reenen, Y., Hoedemaker, E., Agustina, D., Vissink, A., Abbas, F. \& Dijkstra, P.U. 2013. Prevalence and severity of periodontitis in Indonesian patients with rheumatoid arthritis. Journal of Periodontal 84(8): 1067-1074.

Takashiba, S., Ohyama, H., Oyaizu, K., Kogoe-Kato, N. \& Murayama, Y. 1999. HLA genetics for diagnosis of susceptibility to early-onset periodontitis. Journal of Periodontal Research 34(7): 374-378.

Tonetti, M.S., Jepsen, S. \& Jin, L. 2017. Impact of the global burden of periodontal diseases on health, nutrition and wellbeing of mankind: A call for global action. Journal of Clinical Periodontal 44(5): 456-462.

Young, A., Dixey, J., Cox, N., Davies, P., Devlin, J., Emery, P., Gallivan, S., Gough, A., James, D., Prouse, P., Williams, P. \& Winfield, J. 2000. How does functional disability in early rheumatoid arthritis (RA) affect patients and their lives? Results of 5 years of follow-up in 732 patients from the Early RA Study (ERAS). Rheumatology (Oxford) 39: 603-611.

Yuki, M., Toshihiro, M., Shigeto, T. \& Kayo, M. 2017. Distinct patterns of dietary intake in different functional classes of patients with Rheumatoid Arthritis. Topics in Clinical Nutrition 32(2): 141-151.

Nik-Madihah Nik-Azis*, Badiah Baharin \& Nurulhuda Mohd Periodontology Department, Faculty of Dentistry

Universiti Kebangsaaan Malaysia

Jalan Raja Muda Abdul Aziz

50300 Kuala Lumpur, Federal Territory

Malaysia 
Fazalina Mohd Fadzilah \& Mohd Shahrir Mohamed Said Faculty of Medicine

Hospital Universiti Kebangsaan Malaysia

Jalan Yaacob Latif, Bandar Tun Razak Cheras

56000 Kuala Lumpur, Federal Territory

Malaysia
*Corresponding author; email: nikmadihah@ukm.edu.my

Received: 19 April 2018

Accepted: 4 January 2019 